\title{
Demographic and Psychological Determinants of Consumerism and Purchase Intention in the Middle East Markets Fadye Saud Alfayad
}

\author{
Jubail University College, KSA \\ fayad_S@hotmail.com
}

\begin{abstract}
This study explores the way in which the market research function can facilitate entry into developing markets by analysing the demographic, and psychological parameters of the Arab consumers in the gulf countries. After collecting data from real participants $(n=601)$, partial least squares approach to structural equation modelling (PLS-SEM) was used to analyse the latent variables and their indicators. The results indicate that developing markets benefit from in-depth market research functions to flesh out the plan for a product, service or brand. This research function should utilize demographic data to segment the target market into more manageable sections. The psychological determinants which defined the marketing strategies developed ensured that the results were more cost-effective. Although consumer's psychologicallybased behaviour and their demographic variables affect performance in emerging markets, behavioural intention to buy brands in the countries of the Gulf Cooperation Council has the greatest effect. Therefore, affinity marketing with luxurious products would be lucrative if it served such customers.
\end{abstract}

Keywords: Market research; Demographic; Psychological Determinantsl Consumerism; Developing Market; Middle East. 


\title{
المحددات الايموغز افية والنفسية للنزعة الاستهلاكية والنوايا الشرائية في أسواق الأيط الشرق الأوسط
}

\author{
فادي سعود الفياض
}

كلية الجبيل الجامعية، السعودية

fayad_S@hotmail.com

ملخص

تبـــث الدر اسـة الطـرق التـي يمكـن مـن خلالهـا لوظيفـة أبحـاث السـوق تسـهـيل الدخـول إلـى الأسـواق

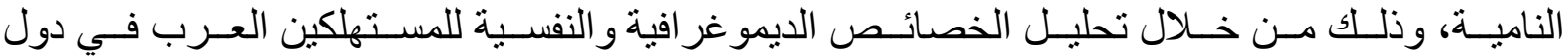

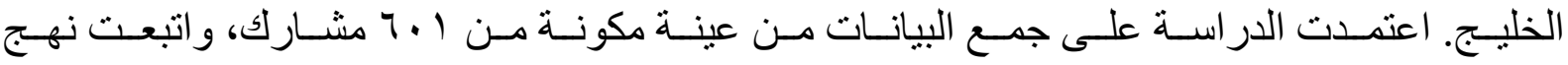

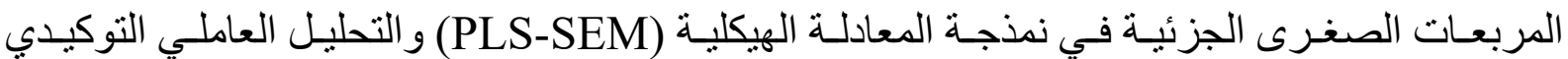

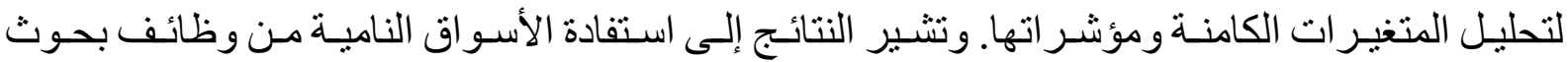

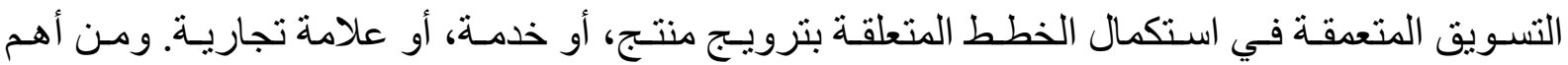

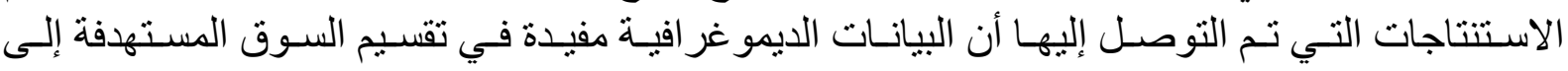

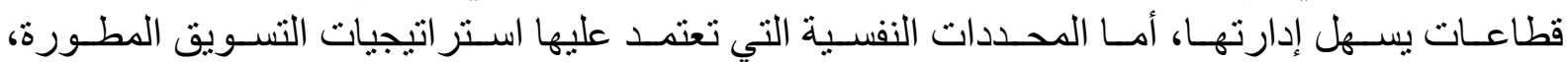

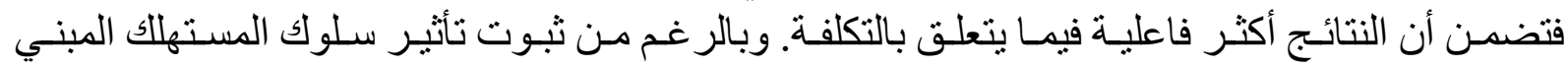

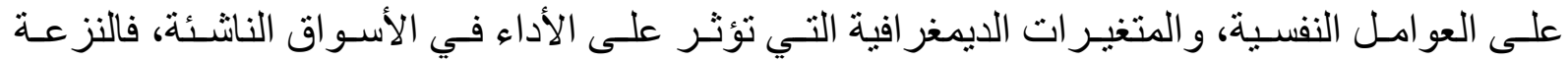

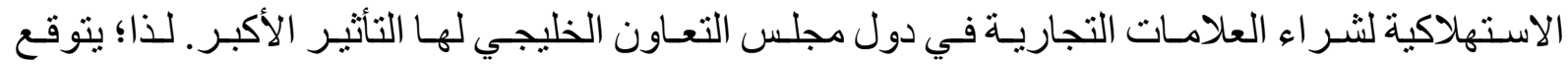

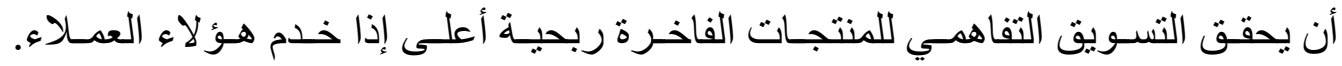

الكلمــات المفتاحيـة: أبحـاث السـوق؛ النزعـة الاسـتهلاكية؛ المحـددات النفسـية؛ الأسـواق الناميـة؛ الثــرق الأوسط. 


\section{Introduction}

Effective marketing depends upon accurate and useful research. The conventional marketing strategy process starts with an analysis of the relevant financial environment, including the five C's - customers, collaborators, competitors, context, and company. Departing from this norm, interactive and digital marketing tactics need strong customer management, the establishment of dynamic channels of communication and sales distribution, prompt and efficient promotion, connectivity of logistics, a reliable supply chain and finance, optimised product management, provision of reimbursement pricing, encouragement of purchasing, and accelerated selling and delivery processes (Stone, \& Woodcock, 2014).

Constructs of rational customer engagement were found to depend on external benefits, emotional attachment, and motivations. An academic attempt was made to connect customer engagement with marketing concepts, market orientation, and relationship marketing, modelling the customer engagement cycle, and developing a customer engagement matrix (Sashi, 2012).

The underlying rationale that informs this study is based on the assumption that consumers are indeed affected by marketing functions. Furthermore, the assumption continues that, by extension, if the marketer's understanding of this effect is realised, then the resulting marketing collateral and strategy become much improved, measured by return on investment or ROI of the marketing costs.

Without linking consumer characteristics to behavioural intention, experience evaluation, and decision making, recommendations about improving future marketing strategies cannot be successfully co-ordinated. Consequently, the purpose of this study is to explore the market function focussing upon demographic and psychological determinants within the region of the Middle East.

\section{Literature Review}

The market research function is not only a marketing-related activity that is necessary for product/service success, but it is also a strategic platform. Marketing strategies should be based on meaningful and practical theoretical knowledge which has a practical, market-oriented purpose. All enterprises entering a developing market, regardless of the product or service, should undertake some form of market research activity in order to remain fully relevant to the markets they are intending to enter. Enterprises may rely on the fundamental continuity of their existing marketing strategy to ensure that their products or services perform in ways that executives view as acceptable (Lim, The \& Ahmed, 2018). Market exigencies always determine marketing strategy, including adaptation and improvisation. A rudimentary understanding of how the market research function affects marketing strategy fails to produce practical data and information relative to how consumers may behave post-entry (Lees-Marshment, 2019). Therefore, a marketing plan which aligns with the business model tends to behave in 
unanticipated ways. Thus, enterprises must and should rely on the market research function to account for such unanticipated behaviours in the marketplace. Market research activity which consists of causal data, descriptive data and, perhaps more importantly, exploratory forms of data, depends on the enterprise's individual product or service-related industry (Morgan et al., 2019). Hence exploratory, descriptive and causal types of data should be integrated into the market research function to develop a more holistic understanding of the character of the target market (Morgan et al., 2019). Additionally, it is also beneficial to approach a specific developing market armed with these data forms collectively. This is because the use of these three forms of data encourages the marketing team and the executives of a firm intending to enter a market to account for certain assumptions beforehand.

\section{Research on Relationship Marketing}

In all contexts, one of the core functions of marketing is the contribution to sales as part of the enterprise's bottom line. Contribution to sales is therefore an important performance indicator for marketing strategies that should not be overlooked. One report stipulates that the awareness of specific sales-related expectations should form part of the nucleus of a marketing strategy's overall rationale (Morgan et al., 2019). Because a traditional marketing campaign retrieved insufficient data on the user-generated feedback, interactive marketing was approved.

Relationship marketing builds a long-term relationship with business partners to minimise behaviour anomalies and increase intention to drum up business. Constructs between relationship marketing practices of trust, commitment, relative dependence, customer satisfaction and perceived value as drivers to intention to continue business relationships under a business-to-business setting are evaluated in Guinness Ghana Breweries. The significance of customer engagement surpassed interactivity, online trust, customer loyalty, advocacy, affective commitment and personalisation (Amoako, Adams, \& Doe, 2020). Theoretical bases of relationship marketing include the Trust-Commitment Theory of relationship marketing (Morgan, \& Hunt 1994), and Social Exchange Theory (Homans, 1958). All endorse the view that relationship marketing must consider customer prospects, customers, clients, advocates, members, and partners.

Cross, Belich and Rudelius (2015) discuss a marketing strategy that facilitated the segmentation of existing consumers using traditional media channels They allowed the marketing enterprise to develop a marketing profile based on web-based data and computationally retrieved information.

Technologies facilitate marketers in the development of focused marketing strategies and generating consumer-related data and information, including self-reported feedback. This type of activity is primarily achieved through a targeted feedback loop that is integrated into the enterprise's established communication channels like instant messaging, email or even opendoor policies (Castenada- et al., 2019). Relationship marketing emphasised that customer 
engagement enhances business performance. Adopting this type of technology solution is a necessity because technology now facilitates data collection, data analysis and data application (Stewart, 2016). Marketing enterprises could potentially benefit from market-based research that focuses on demographic and psychological determinants.

Based on analysing more than 800 incidents involving self-service technologies solicited from customers through a web-based survey, Meuter et al. (2000) categorise these incidents to discern the sources of satisfaction and dissatisfaction within self-service technologies. Customer attributions, complaints, word of mouth, and repeat purchase intentions were considered instrumental in accepting the e-marketing strategies.

\section{Developing Markets in the Middle East}

The Middle East as a region is one that is often overlooked from a developmental standpoint due to the incidences of conflict that have taken place in the region over the past several decades. However, it would be patently unfair to paint the entire region with a broad brush of instability and political turmoil. The Gulf Cooperation Council (GCC) for instance is one such market in the Middle East that is repeatedly touted as a paragon of economic development within its seven-member states which include Bahrain, Kuwait, Oman, Qatar, Saudi Arabia and the United Arab Emirates (UAE). It has consistently produced a gross domestic product (GDP) in excess of \$3.6 trillion, or what amounts to \$71,000 per capita (Gulf, 2019). This regional economic powerhouse is the ideal market in the Middle East to demonstrate the importance and applicability of the market research function. GCC companies adhere to $69 \%$ of the attributes addressed in the CGI. The results also show that the firms listed in the United Arab Emirates stock markets exhibit the best adherence to the CG attributes examined in the study, followed by Oman, Saudi Arabia, Qatar and Kuwait, respectively (Al-Malkawi, Pillai, \& Bhatti, 2014)

Because the GCC is essentially a unified consumer market, there is a degree of standardisation in the marketing strategy that international firms can adopt and adapt for their own use at the market entry level. GCC comprises different national markets, but because of the economic and monetary policy union along with the customs union, the GCC as a whole can be approached with a degree of standardisation not available to other emerging economies. This standardisation in marketing, messaging, branding and strategy upon market entry are largely due to the similar market conditions, permissible firm ownership structures and shared commercial regulations (Ansari \& Riasi, 2016). Branding and messaging customisation are still requisites within the contemporary marketplace regardless of the target market in question. This is because of the ubiquity of social media, online retailing platforms and brand customisation. Certainly, in the GCC, a high level of brand messaging customisation can occur regardless of the developing economic profile of some of its member states. Certain authors have pointed out that dividing effective market research into three core areas is the only way to develop customised marketing messages while still retaining a degree of standardisation in the marketing strategy (Schivinski, Christodoulides \& Dabrowski, 2016). An example of this is provided below. 


\section{Demographic and Psychological Determinants of Customer Engagement}

Customer engagement behaviours (CEB) use word-of-mouth, recommendations, feedback from other customers, blogging, anonymous reviews, and tweets among other things before any intended purchases (McKinney, Yoon, \& Zahedi, 2002). This is because CEB relies on diverse cognitive, emotional, behavioural, and socio-economic elements (Vivek, Beatty, \& Morgan, (2012). Therefore, several models were proposed to explain the topographically-based and culture-oriented differences amongst consumers (Brodie et al., 2011, McKinney et al., 2002; Sashi, 2012; Vivek et al., 2012; Yoon, 2002).

Mahmoud et al. (2019) studied the effect of gender predilection as a demographic factor on the behavioural responses of 829 participants from the Middle East towards permission-based direct email marketing, using structural equation modelling in order to test the hypothesised path model. Given that attitudes were found to mediate the relationship between beliefs and behavioural responses towards permission-based direct email marketing, gender moderates the relationship between beliefs and attitudes in this effect. Middle Eastern female respondents reacted more positively than males to direct email marketing.

Saravanan and Satish (2017) investigated how retail investor purchasing methods vary across concerns of gender and occupation, along with interactive effects on risk attitude and knowledge levels. It was found that males experienced in purchase decisions in private sectors were inclined to take a more active approach, in contradistinction to people of either gender working in government sectors.

The market research function as a process relies on the use and integration of structured data and data collection techniques. Customer engagement with Facebook brand pages was positively influenced by customer motivation, information, remuneration, social interaction and personal identity (de Silva, 2019). Accordingly, we postulated the following hypotheses:

Hypothesis (H)1: Consumer's psychologically-based behaviour affects performance in emerging markets.

$\mathrm{H} 2$ : Consumer psychologically-based behaviour is governed by the purchased product.

H3: Branding affects consumer behaviour.

H4: Branding influences performance in emerging markets.

H5: Consumers' demographic variables influence their behavioural intentions.

H6: The purchased product regulates the consumer's choices.

The proposed research model together with the proposed hypotheses are displayed in Figure 1. The model includes two root constructs relevant to the influence of demographic and psychological determinants of customers' purchasing behaviour of a particular product in a developing market. 


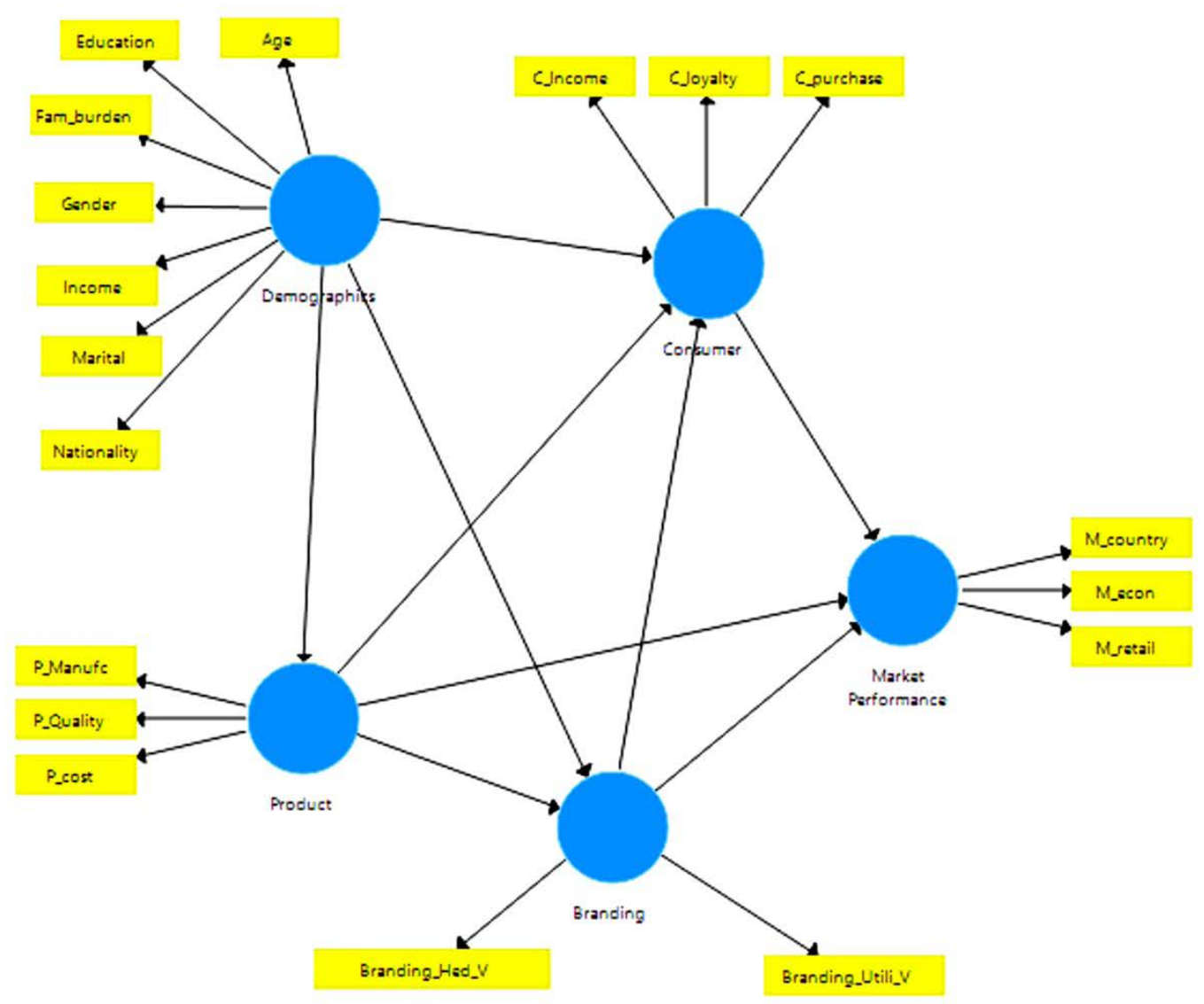

Figure 1. The proposed model

\section{Methodology}

\section{Data Collection}

Several approaches to data collection were utilised for this study. Chiefly, demographic and psychological determinants were collected by using online surveys, and adapting validated scales from previous studies to measure our constructs. The surveys were developed and distributed via SurveyMonkey, which is a well-established professional platform for designing questionnaires and collecting responses. A link to the Likert-style survey was shared. We used the responses which were fully completed, received by the deadline (the data were collected between January 19 to February 15, 2020) and were error-free $(n=601)$. All participants were fully informed as to the aims of the study. Consent was inferred from completion of the survey.

\section{Measures}

We used multi-item scales to evaluate consumer behaviour, demographic variables, market performance, product features and branding influence constructs. A total of 18 items were used to measure five constructs. Reliability and validity were assessed for each latent variable. 


\section{Data Analysis}

The collated data were downloaded from a licensed account in several formats (PDF, Excel sheets and UTF-8 text files). We used SPSS version 25 to measure the internal reliability, normality, variability and kurtosis and to format the data that require further processing. PLSSEM in SmartPLS, version 3.2 was used to test the measurement and structural models (Hair et al., 2016; 2019). The assessment of structural models was carried out, ascertaining relationships between each construct. As a post hoc analysis we ran a partial least squares-multigroup analysis to verify that differences in the model were statistically significant. The post hoc analysis was supported by $t$-tests with calculating the corresponding $\mathrm{p}$-value and running the bootstrapping algorithm.

\section{Results}

The demographic data collected for the study indicated that many respondents were aged between 36 and 65 . Correspondingly the respondent population outside of this age bracket consisted of approximately $30 \%$. Furthermore, 353 out of 601 participants were male, while 256 participants were female. Approximately, $52 \%$ of the respondents reported incomes above $\$ 61 \mathrm{k}$ and $75 \%$ identified themselves as either being married or involved in a live-in relationship of some kind. Finally, $90 \%$ of the respondents were Arab citizens based in GCC. Table 1 displays the basic demographic features collected in this study. 
Alfayad

Table 1. Demographic Profile of the 601 Respondents

\begin{tabular}{|c|c|c|}
\hline Demographic Data & $\mathbf{N}$ values & \% Validity \\
\hline \multicolumn{3}{|l|}{ Age } \\
\hline $25>$ & 135 & 22.8 \\
\hline to 3526 & 127 & 21.5 \\
\hline to 5536 & 138 & 23.3 \\
\hline to 6556 & 118 & 19.9 \\
\hline to 7565 & 73 & 12.3 \\
\hline $76<$ & 2 & 3. \\
\hline \multicolumn{3}{|l|}{ Gender } \\
\hline Male & 353 & 58.9 \\
\hline Female & 256 & 51.1 \\
\hline \multicolumn{3}{|l|}{ Personal incomes } \\
\hline $00015-0$ & 93 & 15.7 \\
\hline $000000-3016$ & 63 & 10.7 \\
\hline $00055-00031$ & 121 & 20.5 \\
\hline $00060-00056$ & 127 & 21.5 \\
\hline up - 00061 & 187 & 31.6 \\
\hline \multicolumn{3}{|l|}{ Educational levels } \\
\hline College Student & 118 & 19.7 \\
\hline 5-year degree/Bachelor's degree & 270 & 55.0 \\
\hline 6-year degree/Master's degree & 182 & 30.3 \\
\hline year degree/Doctorate degree $7+$ & 30 & 5.0 \\
\hline \multicolumn{3}{|l|}{ Marital status } \\
\hline Single & 125 & 20.6 \\
\hline Co-habitating & 115 & 19.0 \\
\hline Married & 269 & 55.8 \\
\hline Widowed & 1 & 2. \\
\hline Divorced & 18 & 3.0 \\
\hline Other & 75 & 12.5 \\
\hline \multicolumn{3}{|l|}{ of Children \# } \\
\hline Yes & 290 & 58.3 \\
\hline No & 310 & 51.7 \\
\hline \multicolumn{3}{|l|}{ Consumers in Household } \\
\hline $1>$ & 90 & 15 \\
\hline consumers 2 & 202 & 33.7 \\
\hline consumers $3-5$ & 259 & 51.5 \\
\hline consumers and up 5 & 59 & 9.8 \\
\hline \multicolumn{3}{|l|}{ Origin } \\
\hline GCC Nationals & 552 & 90.5 \\
\hline Non-nationals & 57 & 9.5 \\
\hline
\end{tabular}


In terms of the psychological data gathered for this study, it was deemed important to collect information according to a set of four general domains. These included the following considerations: 1) environmental perspectives, 2) economic perspectives, 3) retail and consumption-related perspectives, and 4) socio-cultural factors. The rationale for the inclusion of these four determinants was based on the recognition that consumers in the GCC understand that, as their national markets develop, environmental considerations are the price that society pays for such development. Additionally, the rationale also recognises that the economic factors are supported by retail consumption for the most part, and that retail consumption is seen as a leading indicator of economic health and confidence. Finally, the socio-cultural elements are important from a psychological perspective because there are certain divisions among some GCC societies such as those between the large foreign worker populations that many of the GCC markets consist of. Economic diversity also depends upon the ability of individual GCC markets to produce a certain amount of goods and services in order to develop economic independence. This requires a strong national identity on the part of the local populations. We then integrated these features into a marketing mould that fits a better understanding of respondent behaviour in order to measure consumer behaviour, demographic variables, market performance, product features and branding influence constructs.

We assessed reliability with internal consistency and items reliability, whereas validity consists of convergent and discriminant validity. Composite reliability measure was used to assess the internal consistency, while item loadings is measured to weigh each item reliability. Convergent validity was established from the average variance explained (AVE), while FornellLarcker criteria was used to evaluate discriminant validity. CR for all constructs was above the threshold of 0.7. AVE for all constructs was above 0.5 . The variance inflation factor (VIF) assessed the multicollinearity. The highest VIF was below the threshold of 5. Thus, there was no multicollinearity issue in the collated data. With these assessments, our data were considered of a significant level of convergent and discriminant validity. Table 2 shows the retrieved measures. 
Table 2. Composite reliability, VIF and outer weights

\begin{tabular}{|c|c|c|c|c|c|}
\hline \multicolumn{2}{|l|}{ Latent variable } & Indicator & \begin{tabular}{|l|} 
Composite \\
reliability
\end{tabular} & VIF & $\begin{array}{l}\text { Outer } \\
\text { weights }\end{array}$ \\
\hline \multirow{7}{*}{\multicolumn{2}{|c|}{ Demographic factors }} & Age & \multirow{7}{*}{0.551} & 1.438 & 0.146 \\
\hline & & Gender & & 1.278 & \\
\hline & & Marital & & 2.116 & \\
\hline & & Fam_burden & & 2.236 & \\
\hline & & Income & & 1.78 & \\
\hline & & Nationality & & 2.463 & \\
\hline & & Education & & 2.482 & \\
\hline \multirow{8}{*}{ Psychological determinants } & \multirow{3}{*}{ Product } & P_Quality & \multirow{3}{*}{0.681} & 1.075 & 1.075 \\
\hline & & P_Manufc & & 1.024 & 1.024 \\
\hline & & P_cost & & 1.056 & 1.056 \\
\hline & \multirow{3}{*}{ Consumer } & C_Income & \multirow{3}{*}{0.853} & 1.167 & 1.167 \\
\hline & & C_purchase & & 1.425 & 1.425 \\
\hline & & C_loyalty & & 1.241 & 1.241 \\
\hline & \multirow{2}{*}{ Branding } & $\begin{array}{l}\text { Branding } \\
\text { Utili_V_V }\end{array}$ & \multirow{2}{*}{0.921} & 1.103 & 1.103 \\
\hline & & $\begin{array}{l}\text { Branding } \\
\text { Hed_V }\end{array}$ & & 1.103 & 1.103 \\
\hline \multirow{3}{*}{\multicolumn{2}{|c|}{ Market performance }} & M_econ & \multirow{3}{*}{0.783} & 1.251 & 0.453 \\
\hline & & M_country & & 1.02 & \\
\hline & & M_retail & & 1.253 & \\
\hline
\end{tabular}

Complete bootstrapping with 5000 subsamples was implemented for the significance testing of paths. Four relationships were statistically significant. Figure 2 views the structural model results. 


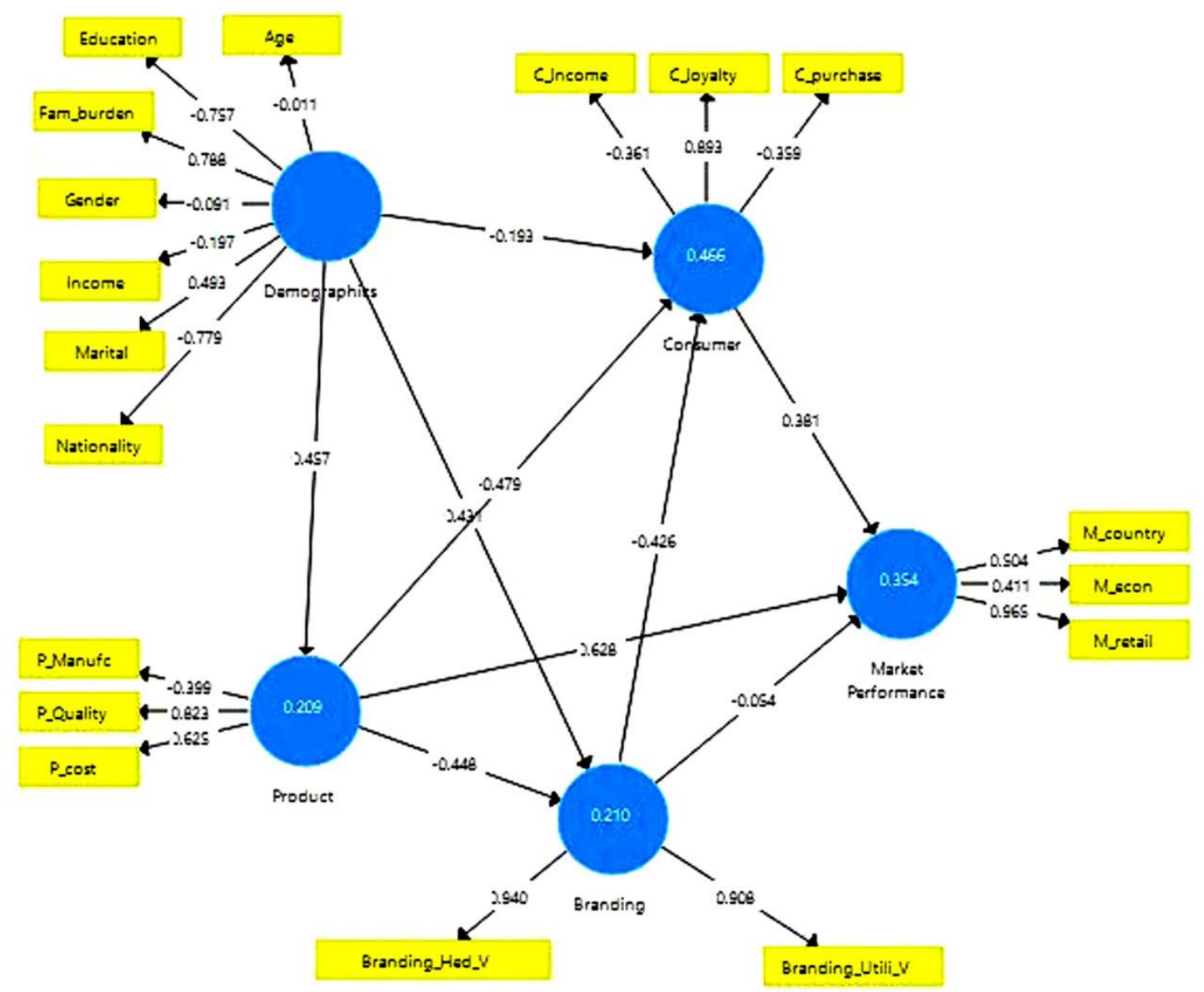

Figure 2. The structural model results

Although consumer's psychologically-based behaviour and their demographic variables affect performance in emerging markets, behavioural intention to buy brands in the countries of the Gulf Cooperation Council has the greatest effect. Therefore, affinity marketing with luxurious products would be lucrative if it served such customers.

GCC residents are generally cognisant of the environmental price that some countries have paid in order to develop economically. They also understand the link between consumerism and environmental damage and costs. Furthermore, many of the respondents clearly support the notion that economic development depends upon having access to disposable incomes and that they must make use of these disposable incomes as part of a thriving marketplace. Many of the respondents also appreciate having access to a surfeit of retail goods and services and view this as a pre-requisite to economic growth and development.

A summary of the data profiles of the study's respondents indicates that the $n$ value of each domain analysed is 179 , while the mean for each differed with the lowest being 3.82 for the retail perspective and the highest average being 5.92 for socio-cultural perspectives. The standard deviations for these domains averaged between.712 and 1.059 respectively, with the 
retail domain receiving the highest standard deviation at 1.059 .

The respondents believed that their participation in national and regional economies is a vital factor in the GCC's development. The respondents also take a certain participatory pride in the GCC's dependence on their consumer-driven support for its development.

As the data above suggests, non-GCC nationals tend to view their participation in the development of the GCC as more discriminatory in nature. Consequently, they tend to feel that they have less choice regarding how they spend their discretionary income and, more critically, how much control they have in generating these discretionary incomes. This type of perspective tends to damage the economic vitality of the GCC as a regional market because a percentage of its residents indicates that they are, in a sense, economically and socio-culturally marginalised.

One final aspect of the data collected relates to respondent demographics and respondent perspectives regarding educational attainment. Perspectives of educational attainment are important from a market development aspect because it is proven that higher levels of educational attainment among a general population tends to contribute to greater economic activity and diversity (Drucker, 2016). Thus, educational levels affect respondent perspectives as well as the degree to which a respondent can participate in the economic activity and development of the region.

According to the data collected, the level of confidence regarding the economy, the size of the disposable income, and the participative engagement with socio-economic factors increase in proportion to the level of educational attainment. Thus, educational factors and educational infrastructure are critical factors in the development of a marketplace such as the GCC.

In this study, the targeted developing market focused upon is that of the GCC. The primary finding related to the demographic profiles of consumers is that demographic data works best when two or more variables are utilised. The selection and application of demographic variables are utilised to develop a demographic profile of an intended target market or audience to which the marketer or marketing strategy is directed. Demographic variables assembled into demographic profiles allow a marketer to generate market segments based on population characteristics.

Psychological variables are identified in the literature as consisting of personality traits, personal consumer characteristics, value systems and beliefs, attitudinal features, personal interests, preferences, and factors such as lifestyle. While demographic data is useful for developing broad consumer areas that can be targeted by marketing strategies, psychological determinants are useful for making these demographic profiles more effective. Psychological determinants reveal consumers' specific needs, wants, likes and desires. Path coefficients are shown in Table 3. 
Table 3. Path coefficients of the studied latent variables.

\begin{tabular}{|l|l|l|l|l|l|}
\hline Latent variable & $\begin{array}{l}\text { Demographic } \\
\text { factors }\end{array}$ & Product & Consumer & $\begin{array}{l}\text { Brand- } \\
\text { ing }\end{array}$ & $\begin{array}{l}\text { Market per- } \\
\text { formance }\end{array}$ \\
\hline $\begin{array}{l}\text { Demographic } \\
\text { factors }\end{array}$ & & 0.457 & 0.193 & 0.431 & \\
\hline Product & & & 0.479 & 0.448 & 0.628 \\
\hline Consumer & & & & & 0.381 \\
\hline Branding & & & 0.426 & & 0.054 \\
\hline
\end{tabular}

The commonalities found within existing research and literature on the subject reveals that the market research function acts as a form of risk mediation in the field. Marketing as a business activity is both a science and an art. Primary consumer data is critical in order to identify demographics and to know psychological determinants. However, understanding how to integrate this data and analysis into a functional marketing plan takes an intuitive grasp of not just the targeted consumer profiles, but also of the intended market, the global factors affecting that market, and intimate knowledge of the firm's internal resources and competencies.

\section{Conclusions}

Relationship marketing research relies on the capacity of marketing analysts to gather, collect and examine all forms of data. This includes primary data collected specifically for ad hoc purposes, which includes data such as demographics, psychological determinants and consumer reports. It also includes secondary data gathered and collected by other parties for specific purposes. Others may then refer to this evidence and utilise it for reference, or for their own marketing strategies.

The research allows marketing related issues to be addressed by using practical data that supports the firm's underlying rationale for a specific developing market. Often, the market research function consists of an exploration of the existing literature in the field. This market research literature removes a lot of unnecessary guesswork from the strategy development process relative to a developing market.

This study has demonstrated how important the market research function is for firms attempting to sell products in developing markets. Specifically, the importance of consumerrelated data including consumer demographic data (personal details), consumer psychological determinants (individual traits), and consumer self-reported data has been shown to be critical in the development of marketing strategies in developing markets within the Middle East region. The specific market that formed the nexus of the analysis and discussion in this regard in the Middle East is the GCC. This is because, for the most part, the GCC has largely avoided the socio-political and geopolitical conflict which has plagued some of the other major markets of the Middle East.

The recommendation that can be made based on the study's analysis and findings is that 


\section{Alfayad}

for any firm entering the GCC, both demographics and psychological determinants need to be considered. Although consumers' psychologically-based behaviour and their demographic variables affect performance in emerging markets, behavioural intention to buy brands in the countries of the Gulf Cooperation Council has the greatest effect. Therefore, affinity marketing with luxurious products would be lucrative if it served such customers. Not only the demographic data and psychological determinants should be collected simultaneously, but they must be obtained through the development and use of separate research instruments as well. 


\section{References}

Adams, K. A., \& Lawrence, E. K. 2018. Research Methods, Statistics, And Applications. Sage Publications.

Al-Malkawi, H. A. N., Pillai, R., \& Bhatti, M. I. (2014). Corporate governance practices in emerging markets: The case of GCC countries. Economic Modelling, 38, 133-141.

Andaleeb, S. S., \& Hasan, K. 2016. Marketing Research. In Strategic Marketing Management in Asia: Case Studies and Lessons Across Industries (pp. 111-160). Emerald Group Publishing Limited.

Ansari, A., \& Riasi, A. (2016). An Investigation of Factors Affecting Brand Advertising Success And Effectiveness. International Business Research, 9(4), 20-30.

Athanasopoulou, P., Giovanis, A. N., \& Avlonitis, G. J. 2015. Marketing Strategy Decisions For Brand Extension Success. Journal of Brand Management, 22(6), 487-514.

Brodie, R. J., Hollebeek, L. D., Jurić, B., \& Ilić, A. (2011). Customer engagement: Conceptual domain, fundamental propositions, and implications for research. Journal of Service Research, 14(3), 252-271.

Castañeda-García, J. A., Frías-Jamilena, D. M., Del Barrio-García, S., \& RodríguezMolina, M. A. (2019). The Effect of message consistency and destination-positioning brand strategy type on consumer-based destination brand equity. Journal of Travel Research, 59(8), 1447-1463.

Cross, J. C., Belich, T. J., \& Rudelius, W. (2015). How marketing managers use market segmentation: An exploratory study. In Proceedings of the 1990 Academy of Marketing Science (AMS) Annual Conference (pp. 531-536). Springer, Cham.

de Silva, T. M. (2019). Building relationships through customer engagement in Facebook brand pages. Marketing Intelligence \& Planning, 38(6), 713-729. doi:10.1108/MIP-02-20190085

Drucker, J. 2016. Reconsidering the regional economic development impacts of higher education institutions in the united states. Regional Studies, 50(7), 1185-1202.

Giesler, M., \& Thompson, C. J. 2016. A tutorial in consumer research: Process theorization in cultural consumer research. Journal of Consumer Research, 43(4), 497-508.

Gulf Cooperation Council. 2019. The World Bank (online). Retrieved from: https://www. worldbank.org/en/country/gcc. Accessed on 29.11.2020.

Hair Jr, J. F., Hult, G. T. M., Ringle, C., \& Sarstedt, M. (2016). A primer on partial least squares structural equation modeling (PLS-SEM). Sage publications.

Hair, J. F., Risher, J. J., Sarstedt, M., \& Ringle, C. M. (2019). When to use and how to 
report the results of PLS-SEM. European Business Review. 31(1), 2-24. doi:10.1108/EBR-112018-0203

Hulland, J., Baumgartner, H., \& Smith, K. M. (2018). Marketing Survey Research Best Practices: Evidence and recommendations from a review of JAMS articles. Journal of the Academy of Marketing Science, 46(1), 92-108.

Lim, W. M., Teh, P. L., \& Ahmed, P. K. (2018). It is not about what you read, but how you read it: The effects of sequencing rational and emotional messages on corporate and product brand attitudes. Journal of Strategic Marketing, 26(4), 339-355.

Mahmoud, A. B., Grigoriou, N., Fuxman, L., Hack-Polay, D., Mahmoud, F. B., Yafi, E., \& Tehseen, S. (2019). Journal of Research in Interactive Marketing. 13 (2), 227-248. doi:10.1108/ JRIM-09-2018-0112

Mayoh, J., \& Onwuegbuzie, A. J. (2015). Toward a conceptualization of mixed methods phenomenological research. Journal of Mixed Methods Research, 9(1), 91-107.

McKinney, V., Yoon, K., \& Zahedi, F. M. (2002). The measurement of webcustomer satisfaction: An expectation and disconfirmation approach. Information Systems Research, 13(3), 296-315.

Meuter, M. L., Ostrom, A. L., Roundtree, R. I., \& Bitner, M. J. (2000). Selfservice technologies: understanding customer satisfaction with technology-based service encounters. Journal of Marketing, 64(3), 50-64.

Milosevic, A., Tosovic-Stevanovic, A., \& Primorac, D. 2019. Model for analyzing market and activities of marketing managers for improving business operations. In Economic and Social Development (Book of Proceedings), 42nd International Scientific Conference on Economic and Social Development (p. 1).

Morgan, N. A., Whitler, K. A., Feng, H., \& Chari, S. 2019. Research in marketing strategy. Journal of the Academy of Marketing Science, 47(1), 4-29.

Saravanan, S., \& Satish, R. (2017). Perception and behavioural intention of retail investors: initial public offers in Indian scenario. SCMS Journal of Indian Management, 14(4), 64-75.

Sari, H., \& Nurhadi, D. A. 2019. Designing Marketing Strategy Based on Value from Clothing-producing Companies Using the AHP and Delphi methods. Jurnal Teknik Industri, 20(2) 191-203.

Sashi, C. M. (2012). Customer engagement, buyer-seller relationships, and social media. Management Decision. 50 (2), 253-272. doi:10.1108/00251741211203551.

Schivinski, B., Christodoulides, G., \& Dabrowski, D. 2016. Measuring consumers' engagement with brand-related social-media content: development and validation of a scale that identifies levels of social-media engagement with brands. Journal of Advertising 
Research, 56(1), 64-80.

Stewart, D. W. (2016). Where is marketing research headed in the $21^{\text {st }}$ century?. Journal of Cultural Marketing Strategy, 1(2), 189-192.

Stone, M. D., \& Woodcock, N. D. (2014). Interactive, direct and digital marketing. Journal of Research in Interactive Marketing, 8 (1) 4-17. doi:10.1108/JRIM-07-2013-0046

Van Auken, S. (2015). From consumer panels to big data: An overview on marketing data development. Journal of Marketing Analytics, 3(1), 38-45.

Vivek, S. D., Beatty, S. E., \& Morgan, R. M. (2012). Customer engagement: Exploring customer relationships beyond purchase. Journal of Marketing Theory and Practice, 20(2), 122-146.

Yoon, S. J. (2002). The antecedents and consequences of trust in online-purchase decisions. Journal of Interactive Marketing, 16(2), 47-63. 
Alfayad

Appendix 1. Questionnaire

\section{Section 1: Demographic variables}

Place an $\boldsymbol{X}$ in the box to indicate the answer of your choice or write your response on the line.

1. How old are you?

2. What is your gender?

Male

Female

3. What is your average annual income level?

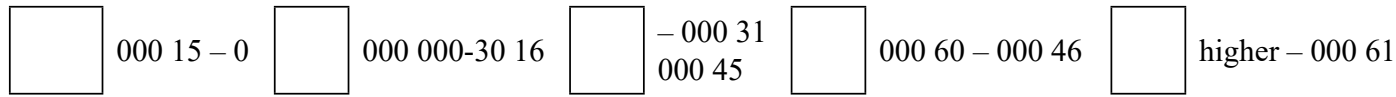

4. What is your highest level of educational achievement?

口 College Student

$\square \quad$ Bachelor's degree

口 Master's degree

口 Post-Graduate

5. What is your marital status?
$\square \quad$ Single
$\square \quad$ living together
$\square \quad$ Married
$\square \quad$ Widowed
$\square \quad$ Divorced
$\square$ Other

6. Do you have dependent children?

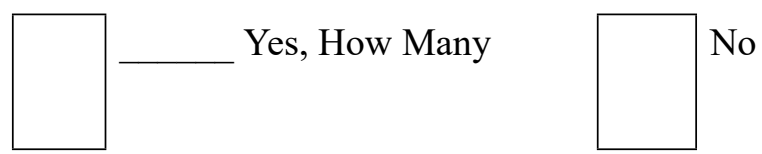

7. If you have dependent children, how old are they?
$\square \quad$ From 0 to 6 years
$\square \quad$ From 6 to 12 years
ㅁ $12-18$

8. How many individuals live in your household?
$\square \quad 1$ person
$\square \quad 2$ people
3-4 people
5 or more people 


\section{What is your nationality?}

$\begin{array}{ll}\square & \text { Bahrain } \\ \square & \text { Kuwait } \\ \square & \text { Oman } \\ \square & \text { Qatar } \\ \square & \text { Saudi Arabia } \\ \square & \text { UAE }\end{array}$

Section 2: Psychological determinants Data

\begin{tabular}{|l|c|c|c|c|c|}
\hline Psychological determinants Statements & $\begin{array}{c}\text { Strongly } \\
\text { disagree }\end{array}$ & Disagree & Neutral & Agree & $\begin{array}{c}\text { Strongly } \\
\text { agree }\end{array}$ \\
\hline $\begin{array}{l}\text { Consumers are vital to the regional (10 } \\
\text { economy }\end{array}$ & 1 & 2 & 3 & 4 & 5 \\
\hline $\begin{array}{l}\text { The economy depends upon consumer (11 } \\
\text { spending at the local, national \& regional } \\
\text { levels }\end{array}$ & 1 & 2 & 3 & 4 & 5 \\
\hline $\begin{array}{l}\text { Retail goods and the retail industry (12 } \\
\text { improve employment rates }\end{array}$ & 1 & 2 & 3 & 4 & 5 \\
\hline $\begin{array}{l}\text { I buy retail products based on quality (13 } \\
\text { and not price }\end{array}$ & 1 & 2 & 3 & 4 & 5 \\
\hline $\begin{array}{l}\text { I buy retail products based on price and (14 } \\
\text { not quality }\end{array}$ & 1 & 2 & 3 & 4 & 5 \\
\hline $\begin{array}{l}\text { Retail goods that are produced in the (15 } \\
\text { GCC are preferable to imported goods }\end{array}$ & 1 & 2 & 3 & 4 & 5 \\
\hline $\begin{array}{l}\text { Imported products damage the local and (16 } \\
\text { national economy }\end{array}$ & 1 & 2 & 3 & 4 & 5 \\
\hline $\begin{array}{l}\text { My salary does not have much in the (17 } \\
\text { way of disposable income }\end{array}$ & 1 & 2 & 3 & 4 & 5 \\
\hline $\begin{array}{l}\text { Not all countries in the GCC are very (18 } \\
\text { strong economically }\end{array}$ & 1 & 2 & 3 & 4 & 5 \\
\hline $\begin{array}{l}\text { My home contains a lot of consumer (19 } \\
\text { product goods }\end{array}$ & 1 & 2 & 3 & 4 & 5 \\
\hline I prefer brand name products (20 & 1 & 2 & 3 & 4 & 5 \\
\hline I prefer generic branded products (21 & 1 & 3 & 4 & 5 \\
\hline
\end{tabular}

